\title{
Hedging Seasonal Food Price Risks: The Impact of Cereal Banking in the Gambia
}

\author{
Raymond Jatta
}

\subsection{Introduction}

In rural communities of the Gambia, as in the case of most other arid and semiarid countries in the world, cereal banking is a common practice to store food at harvest for use during lean periods. It is a community-based strategy of making food available throughout the year and managing seasonal food price dispersions by maintaining physical food reserves (Beer 1990). It aims at managing price and climate risks.

Rainfall variability and food price volatility are some of the most important risk factors that affect lives and livelihoods of poor rural households in importdependent countries such as the Gambia (Vicarelli 2011, p. 2; Wright and Cafiero 2009). This is due in part to their primary sector-based economy (which is sensitive to climate conditions), their reliance on food imports, and their low levels of human development and food accounting for a major part of their income and expenditure (Kalkuhl et al. 2013; Wheeler and von Braun 2013; FAO 2011). These factors account for high human costs resulting from climate and market shocks (FAO 2011; von Braun and Tadesse 2012; Ivanic and Martin 2008).

In this chapter, we assess how cereal banking can be used as a viable option in rural communities to enhance food and livelihood security in the face of climate and price risks. In spite of cereal banking's popularity in most of the arid and

\footnotetext{
R. Jatta (州)

University of Cheikh Anta Diop, Dakar, Senegal

e-mail: raymondjatta@yahoo.co.uk
} 
semiarid rural communities (Basu and Wong 2012; Bhattamishra 2012), the practice has received little empirical scientific research.

\subsection{Context}

Our study was conducted in 134 rural communities, in a total of 13 districts from three of six rural regions in the Gambia. $78 \%$ of the active population in the Gambia is engaged in rain-fed subsistence farming as a source of income and food. Households in rural areas are generally larger ( $>12$ members) and poorer, with $48 \%$ of the households below the national poverty line of $\$ 1.08$ a day (GoG 2010). The traditional land tenure system allows for small land holdings inequitably distributed among men and women (von Braun et al. 1989; Carney 1992). In addition to other socioeconomic factors - such as urbanization, population growth, inadequate input supply and the use of crude technology-rainfall variability has an important multiplier effect on the ability of households to feed themselves. The Gambia's climate is Sahelian semiarid. Its location has been described as a hotspot for climate change and food insecurity (Ericksen et al. 2011). The climate consists of two seasons: a 4-month rainy season (June-September) and an 8-month dry season. Because the rainy season is short, only a single cropping season is feasible for rain-fed agriculture ${ }^{1}$ (Ceesay 2004). Only about $50 \%$ of the country's food needs is produced locally (WFP 2011). The Gambia is thus regarded as a food-deficit, import-dependent country. Inter-annual variations in food production generally follow rainfall trends and variability.

Figure 22.1 shows an almost perfect positive correlation between rainfall variability and cereal production variability. Variability in Fig. 22.1 is a measure of dispersion of each annual rainfall or production figure from their mean between 1991 and 2012, normalized by their standard deviation.

Figure 22.2 shows the gap between domestic consumption and production. Rainfall variability has the potential to reduce domestic production. When coupled with a global food crisis and a price hike, it could cause food prices to rise drastically, eroding purchasing powers and resulting in poverty and malnutrition among many Gambians (Kalkuhl et al. 2013). Given the country's dependence on food imports ${ }^{2}$ (60\% estimated by Tadesse et al. 2013), any changes in global food availability and food prices will definitely affect foreign exchange rates, causing inflationary pressures on food and non-food imports.

Food production, affordability, and consumption in rural areas of the Gambia follow the agricultural cycle (Barrett 1996), as in most developing countries. During harvest season, food is in abundance, and most households become net suppliers of food. In the Gambia, the harvest season spans from October to February. Food supplies tend to move from rural to urban areas because of higher prices (a

\footnotetext{
${ }^{1}$ Irrigated area is less than $6 \%$ of arable land.

${ }^{2}$ WFP (2011) estimates $81 \%$ dependence on rice imports, the country's staple food.
} 


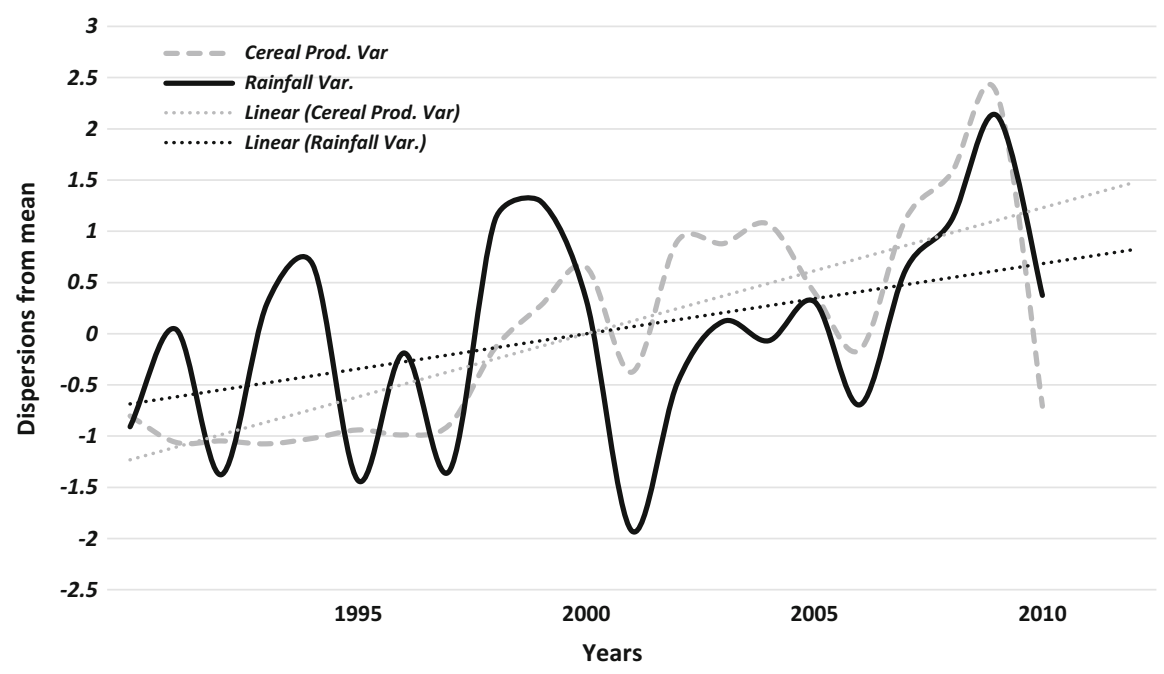

Fig. 22.1 Crop production and rainfall variability, 1991-2012. Source: Department of Water Resources, Gambia

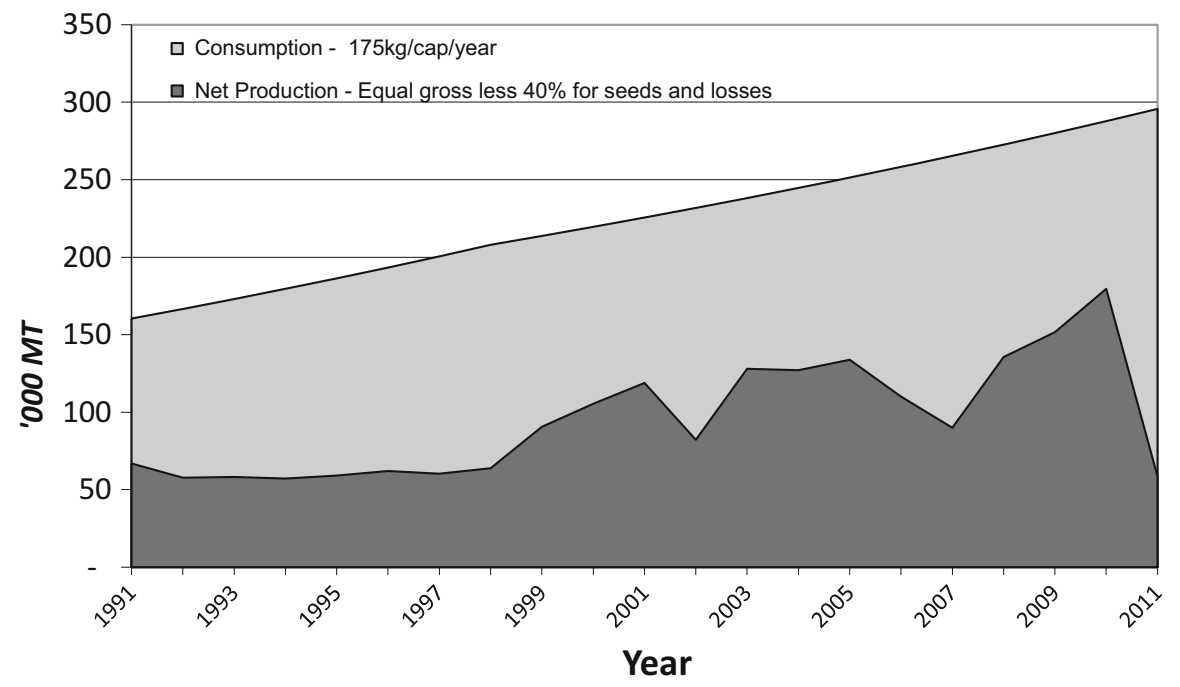

Fig. 22.2 Consumption requirement vs. net cereal production 1991-2011. Source: World Food Programme-WFP (2011). Note: consumption requirement in the Gambia in 1000 metric tons to meet a cereal demand of $175 \mathrm{~kg} / \mathrm{cap} / \mathrm{year}$

consequence of higher demand) in the urban areas (Barrett 1996). However, food is usually in short supply when approaching the rainy season (FAO 2011). Rural households and communities become net buyers and often have to rely on imported food from the urban areas. The reversal of food flow begins driving upwards food 
prices in rural areas. Production constraints, exacerbated by the absence of large storage schemes and credit constraints, tend to worsen the price changes and the spatial and temporal food availability (Barrett 1996). The transition in terms of the duration of the food gap is influenced by rainfall patterns, among other things. In years with low rainfall, inter-seasonal food price dispersion can be as high as up to $400 \%$ (von Braun et al. 1999). This dynamic affects rural households and communities more-eroding incomes and causing seasonal food and nutrition insecurity (WFP 2011). As a result, the problem of food insecurity is more seasonal than chronic in rural areas of the Gambia. Every year, poor households in the rural areas face the "hungry season," a period of 3-4 months between July and September, when household food stocks are low or depleted (FAO 2011). The Comprehensive Food security and Vulnerability Assessment Report (WFP 2011) observed that in the months of August and September, about $80 \%$ of the rural households reported food-insecure conditions, while only $10 \%$ reported being food insecure between December and April. Similar studies on seasonal food security programs in East Indonesia and Bangladesh (Basu and Wong 2012; Khandker 2009 respectively) observed similar seasonal food insecurity dynamics.

\subsection{Methodology}

Our methodology is based on a large scale randomized control trial (RCT) implemented in the Gambia called the Community Driven Development Project (CDDP). The project, funded by the World Bank, was implemented in the Gambia from 2008 to 2011. Using a poverty index as a basis for stratification, 930 out of about 1800 villages were eligible, and of the 930 eligible villages, 495 were randomly chosen for the CDDP intervention (Arcand et al. 2010). 35 of the 495 villages chose cereal banking from a wide range of possible projects based on the needs and aspirations of their communities. ${ }^{3}$

We note that while selection for CDDP intervention was randomized, the choice of subprojects such as cereal banking was not. It was likely influenced by endogenous village characteristics. Evaluating the impact of such subprojects requires the use of quasi-experiments (Abebaw and Haile 2013).

Subsequently, we have to investigate the determinants making these villages choose cereal banking for their subproject. These factors must be controlled to minimize selection bias and fulfil the Conditional Independence Assumption (CIA) (Heckman et al. 1997; Angrist and Pischke 2008).

\footnotetext{
${ }^{3}$ Participatory project identification methods were used; villagers chose the subproject at village meetings.
} 


\subsubsection{Propensity-Score Matching}

In propensity-score matching (PSM), researchers try to balance groups by matching treatment and control units based on the characteristics that affected their probability of receiving treatment—which, in this case, is cereal banking (Heckman et al. 1997; Caliendo and Kopeinig 2008). PSM ensures that at baseline and on average, groups are identical in terms of observed characteristics (Heckman et al. 1997; Caliendo and Kopeinig 2008). The method requires finding a control group which bears similar characteristics as the treatment group in all respects; however, the control group does not receive treatment. If a treated group and a potential control group have matching propensity scores, then the difference between outcomes of the two groups is an unbiased estimator of the treatment effect (Heckman et al. 1997; Ravallion 2007; Abebaw and Haile 2013). However, this assumption becomes invalid if there are important unobservable factors that affect treatment and outcomes (Caliendo and Kopeinig 2008). The method can be improved by using fixed effects which captures time-invariant unobserved heterogeneities (Olken 2012).

We estimate the propensity of a community participating in a cereal banking scheme using a nonparametric logit model:

$$
P(\mathrm{CB})=\beta \mathrm{Vc}(i)+\varepsilon(i),
$$

where $P(\mathrm{CB})$ is the probability of participating in a cereal bank; $\beta$ represents parameters that must be estimated; $\mathrm{Vc}(i)$ is a vector of a village's preexposure level of social, economic, livelihood, natural, and market characteristics; and $\varepsilon$ is an error term. On the basis of the CDDP assignment, we conducted PSM using two subsamples:

- Matching cereal banking villages with CDDP-funded villages that opted for subprojects other than cereal banking (partial control group)

- Matching cereal banking villages with villages that neither benefitted from the CDDP funding, nor had cereal banking schemes (pure control group)

\subsubsection{The Propensity-Score Matching Results}

Data for the PSM were obtained from the 2003 National Population Census data and National Agricultural Sample Survey 2007. From a total of 827 villages in all the six rural regions in the Gambia, 22 pretreatment village variables were generated for our PSM. Relative to the sample size of the treatment group (35), the large sample size of possible control villages (780) ensures that the pretreatment mean differences between the treated and their matched counterfactuals converge to zero (ChabéFerret 2010), thus reducing sample selection based on observables (Baker 2000; Heckman et al. 1997). A one-to-one nearest-neighbor matching algorithm without replacement was employed as it enhances efficiency and reduces biases (Caliendo 
and Kopeinig 2008, p. 9). It also matches each treatment village to a unique village from the pure control and the partial control groups.

The results of our PSM indicate the variables that influenced the villages to choose cereal banking. Overall, the $R^{2}$ indicates that our PSM model [Eq. (22.1)] has strong explanatory power for the probability of a village choosing cereal banking. Out of the 22 variables, 13 were statistically significant at $10 \%$ significance level, while 9 were statistically significant at $5 \%$ significance level. Our coefficients are expressed in odd ratios and not in marginal effects, but the $\mathrm{p}$ values indicate the level of significance for each of the variables (Table 22.1).

The PSM results provide the following insights:

- Coefficient of variation of the prices ${ }^{4}$ (Huchet-Bourdon 2011) of the main food crops in a village market, or in the market closest to the village, ${ }^{5}$ indicates price dispersion and price risk. Our results show that communities facing high price risk tend more to choose cereal banking. This is in agreement with existing studies (Bhattamishra 2012; Cortès and Carrasco 2012).

Table 22.1 Results of propensity-score matching

\begin{tabular}{l|l|l|l|l}
\hline \multirow{2}{*}{ Variable } & \multicolumn{3}{|l|}{ Partial control PSM } & \multicolumn{2}{l}{ Pure control PSM } \\
\cline { 2 - 5 } & Coefficient & $P>|z|$ & Coefficient & $P>|z|$ \\
\hline Coefficient of variation (rainfall) & 13.8706 & 0.286 & 16.076 & 0.246 \\
\hline Coefficient of variation (price) & 660.3531 & $0.006^{* *}$ & 681.091 & $0.018^{*}$ \\
\hline Poverty & 7.2494 & $0.035^{*}$ & 2.695 & 0.408 \\
\hline Availability of fruit trees & -0.0512 & $0.033^{*}$ & -0.043 & 0.102 \\
\hline Millet grown & 0.00134 & $0.004^{*}$ & 0.001 & $0.009^{*}$ \\
\hline Proportion of crop farmers & 46.2541 & $0.029^{*}$ & 32.713 & 0.053 \\
\hline Average HH size & 0.7248 & 0.209 & -0.283 & 0.501 \\
\hline Prop of Hhs without daily market & 0.1836 & $0.046^{*}$ & 0.152 & 0.058 \\
\hline Prop of Hhs without improved trans. & 0.5373 & $0.009^{*} *$ & 0.476 & $0.038^{*}$ \\
\hline Dominant ethnicity gr. 3 & 14.6823 & $0.003^{* *}$ & 7.953 & $0.09 * *$ \\
\hline Dominant ethnicity gr. 2 & 7.4451 & $0.004^{* *}$ & 3.842 & 0.113 \\
\hline Connected and lowland villages & 1.1066 & 0.109 & 1.618 & $0.039^{*}$ \\
\hline Distance to market & 0.5274 & $0.038^{*}$ & -0.446 & $0.033^{*}$ \\
\hline Proximity of the LGA & 33.20208 & $0.024^{*}$ & 33.592 & $0.02^{* *}$ \\
\hline Proximity of the district & 2.873271 & $0.021^{*}$ & -3.023 & $0.016^{*}$ \\
\hline Cov_Price2 & 1128.559 & $0.004^{* *}$ & -1157.499 & $0.016^{* *}$ \\
\hline No. of observations & 451 & & 422 & \\
\hline R2 & 0.4549 & & 0.3947 & \\
\hline P < & & & & \\
\hline
\end{tabular}

$* P<0.05, * * P<0.01$

\footnotetext{
${ }^{4}$ See Huchet-Bourdon (2011).

${ }^{5}$ The price data is collected from 28 markets in the Gambia on a monthly basis.
} 
- Access to market is measured by the distance from a village to the closest weekly market. The availability of improved transport systems indicates if a village is connected or remote. The more isolated a community is, the higher the probability that it will choose cereal banking. This is similar to findings of existing studies (Afrique Verte 2010; Bhattamishra 2012). A great distance to markets may motivate communities to store food because households in these villages may incur high transaction and transportation cost, Daviron and Douillet 2013).

- The probability of choosing cereal banking is significantly different between communities with food surplus and those with food deficit (Bhattamishra 2012; Cortès and Carrasco 2012). Lowland villages, which are in close proximity to the River Gambia - a source of fresh water for irrigation - often have more favorable environment for farming (Ceesay 2004; von Braun et al. 1989). In most cases, they produce more food crops, especially rice, relative to the villages located in the upland. A review of the choice of subprojects for the CDDP show that most of the communities in the lowlands opted for production enhancement equipment, access to fields, and gardening, rather than cereal banking (Arcand et al. 2010).

In general, the results of the PSM show that villages that are poor, remotely located, and susceptible to rainfall and price volatility are more likely to choose and maintain a cereal banking schemes (Cortès and Carrasco 2012; Bhattamishra 2012). This highlights the importance of targeting the right villages when implementing a program since not all communities equally need, or can sustain, a cereal banking schemes.

The $T$-test (in Annex on Table 22.5 below) shows that before matching, some significant differences between treated and non-treated villages were observed. However, after matching, there are no significant differences between the two groups. Unlike earlier researches that used PSM, our method gives superior results because the PSM is built on both stratification and randomization (Arcand et al. 2010; Abebaw and Haile 2013). Using propensity-score nearest-neighbor matching, we were able to generate a control group similar enough to the treatment group, so that the impacts of cereal banks can be evaluated.

\subsection{Impact Evaluation}

Based on the PSM results, 134 villages were selected for the survey. Then we randomly selected $10 \%$ of the households in each village (a total of 460 households). Using this cross-sectional data (Olken 2012), we estimated the average treatment effect (ATE) and the average treatment effect on the treated (ATET). Our analysis focuses on indicators of food security, nutrition security, and livelihood security. Taking our cue from recent literatures about the conceptualization and measurement of food and nutrition security (Hoddinott 1999; Pangaribowo et al. 2013; Pieters et al. 2013; Laborde Debucquet et al. 2013; Kalkuhl et al. 2013; 
von Braun and Tadesse 2012), we considered various aspects of food security: availability, accessibility, utilization, and stability.

\subsubsection{Empirical Strategy}

In the first set of analysis, we compared the mean outcomes to determine if there are any differences in DIM between the treatment, pure control, and partial control groups. This is to determine if any of the effects can be reasonably attributed to the treatment. Since the pretreatment characteristics of villages were considered in the matching process, any differences in the outcomes can be attributed to the treatment (Ravallion 2007). Therefore, the DIM indicates the ATE.

\subsubsection{Comparison of Means: Treated and Control Villages}

As in the PSM, we found that most of the villages remained unchanged in their physical and socioeconomic features 4 years after implementing the project. This further validated our PSM. However, among villages, there are also some important DIM, some of which indicate the ATE of the program (Becker and Ichino 2002).

The households had a food gap of more than 2.5 months on average. The food gap, also called the lean period or hungry season (FAO 2011), represents the number of months a household reports not having adequate food stocks or money to buy food. The households often need to hire out their own labor for money or to take out a loan. We observed significant differences in the length of lean period among the households sampled. ${ }^{6}$ While households in treated villages experienced an average 2.1 months of food gap, the pure control group experienced almost 3 months of food gap, and the partial control group 2.5 months. Comparing the treated group and the pure control group, cereal banking reduces the length of lean period by $25 \%$.

The results for the selling prices of cash crops (groundnut at harvest) and the buying prices of food crops (millet and maize during the lean period) also indicate a significant difference between the treatment and control villages. The price effect is more significant when comparing treated villages and partial control villages. This indicates that variations in food and cash crop prices is higher in partial control villages than in the other two groups, suggesting that in the absence of a food storage, households may produce more food and yet achieve lower incomes. Variation is defined as the difference between prices of food crops (rice, maize, and millet) reported in August (lean period) and price of cash crops (groundnut) reported in December (harvest period) minus the yearly average prices of the same crops.

Figure 22.3 shows that at harvest, when most rural households are net sellers, the selling prices of excess production are $16 \%$ lower in control villages than treated villages. In contrast, during the lean period, when most rural households are net

\footnotetext{
${ }^{6}$ The lean period or hungry season in the Gambia often starts in July-September.
} 


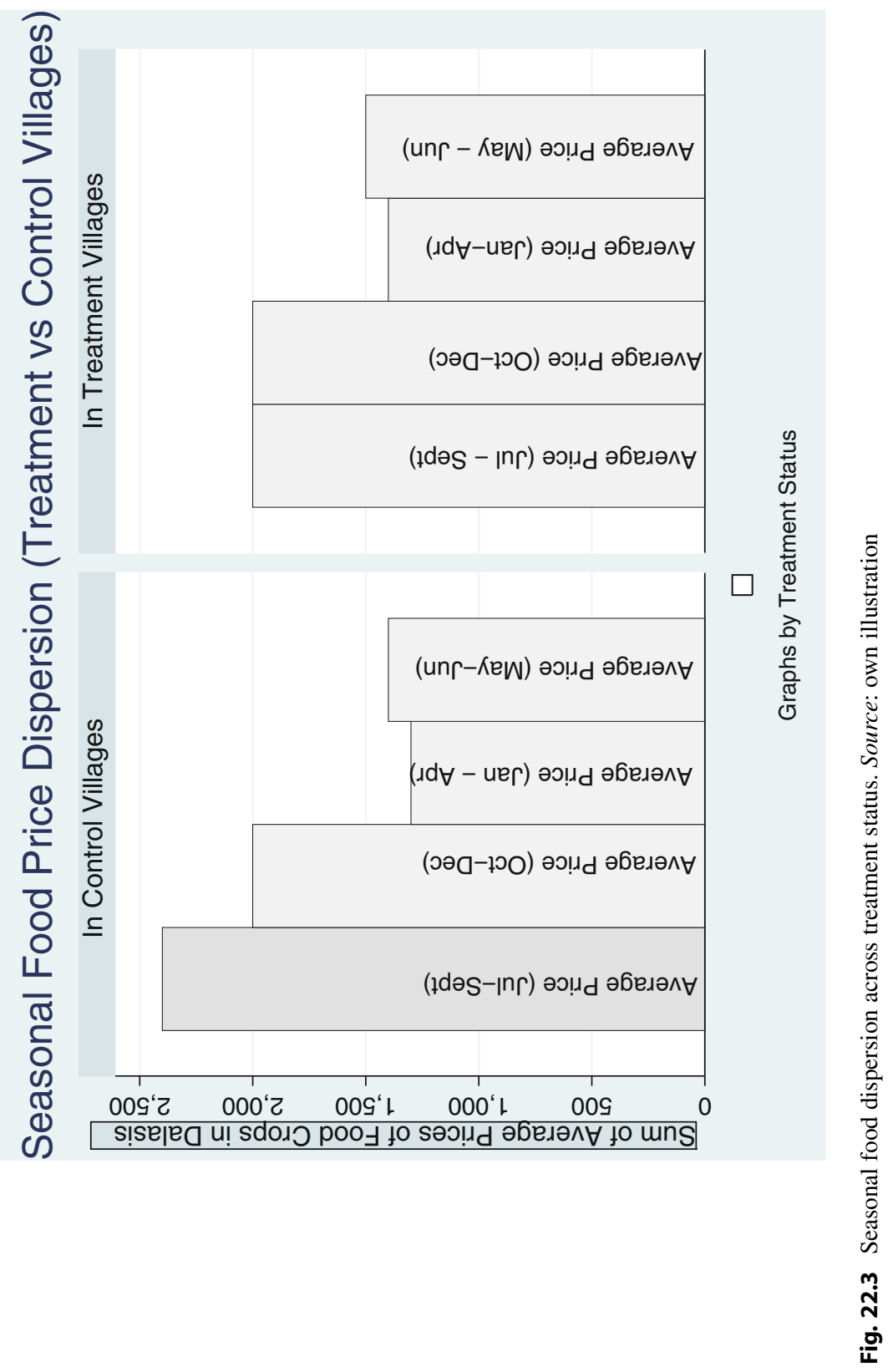


buyers, the buying prices of cereals are significantly lower in control villages than treated villages (about $15 \%$ lower). This implies selling farm produce at lower prices and buying food at higher prices for households in control villages compared to those in treatment villages, contrary to conclusion in Kent (1998).

The following may explain the differences in prices and price variability:

- Households in treated communities reported higher dependency on their own production for food than those in control group. Thus, treated communities sell less of their food crops at harvest and buy less food during the lean period, signifying that they become net buyers of food much later than the control group.

- Cereal banking schemes disincentivize speculative arbitrage, often carried out by middlemen, moneylenders, and input lenders (Cortès and Carrasco 2012; Kent 1998). As shown in the DIM in Table 22.2, middlemen are more active in control villages than in treated villages. In the Gambia, middlemen and moneylenders lend food or inputs to households. Similar to the findings of other empirical studies in this field (Cole et al. 2012; Morduch 1995; Cortès and Carrasco 2012), it was observed that when risk management strategies or one form of credit scheme are in place, there will be less demand for other forms of credit (Gilbert 2012).

- Similar to other research findings, inter-seasonal price changes are more significant for domestically produced food (millet and maize). Compared to other similar studies (Afrique Verte 2010; von Braun et al. 1999; Bhattamishra 2012), this study found a slightly lower, but nonetheless significant, inter-seasonal price change between harvest and lean seasons: $53 \%$ in treated villages and $84 \%$ in control villages. The treated villages showed a 31 percentage point reduction in inter-seasonal price variation.

Table 22.2 Mean outcomes-treated and control villages

\begin{tabular}{l|l|l|l|l|l}
\hline & Treated & Pure control & Test & Partial control & Test \\
\hline Food gap & 2.170 & 2.830 & $0.00 *^{* *}$ & 2.490 & $0.047^{*}$ \\
\hline Price cash crop-harvest & 726.470 & 625.000 & $0.003 * *$ & 587.230 & $0.000^{* *}$ \\
\hline Price food crop_lean & 918.570 & 1057.970 & $0.002 * *$ & 959.780 & 0.177 \\
\hline $\begin{array}{l}\text { Variation in cash crop } \\
\text { prices-harvest }\end{array}$ & -178.180 & -192.910 & 0.350 & -246.660 & $0.026^{*}$ \\
\hline $\begin{array}{l}\text { Variation in food crop } \\
\text { prices-lean }\end{array}$ & 114.280 & 262.640 & $0.000^{* *}$ & 238.630 & $0.000^{* *}$ \\
\hline $\begin{array}{l}\text { Price of imported rice } \\
\text { Self-help groups }\end{array}$ & 1159.14 & 1155.850 & 0.775 & 1153.640 & 0.639 \\
\hline $\begin{array}{l}\text { Ward Development } \\
\text { Committee membership }\end{array}$ & 1.9 & 1.6 & 0.665 & 1.7 & 0.872 \\
\hline $\begin{array}{l}\text { Moneylenders/middlemen } \\
\text { Number of villages }\end{array}$ & 1.4 & 1.927 & 0.894 & 1.979 & 0.895 \\
\hline
\end{tabular}

$* P<0.05, * * P<0.01$

${ }^{a}$ Variation in cash crops at harvest and food crops at the lean period are the difference of the price at harvest/lean minus the mean price during the year 
Our study also found that there are more local self-help groups in the treated villages than the control villages. This indicates that when compared to the control villages, the treated villages are likely to have created more internal networks and have better capacity to initiate, implement, and sustainably manage their self-help projects. The treated villages are also significantly more socially connected, having much more representation in ward- and district-level organizations, such as the Ward Development Committee (WDC).

In addition, households in the treated villages tend to be more effective at adapting to changes (Maxwell and Smith 1992) than their counterparts in the control villages. For example, treated communities were more likely to introduce new varieties of crops and use extensive production systems (although the latter is not always sustainable), and their population less likely to migrate.

\subsubsection{Estimating Treatment Effect on the Treated}

To evaluate the impact of the cereal banking scheme, we conducted a regression analysis to estimate the actual ATET or the intention to treat (ITT) (Arcand et al. 2010; Duflo et al. 2007).

Our regression model at village level can be described using the equation:

$$
Y(i)=\alpha(w)+\pi V(i)+\beta T(i)+\varepsilon(i),
$$

where $Y(i)$ is the outcome variable of village $i, \alpha$ represents baseline village characteristics which allows for estimation with and without fixed effects $(w), V(i)$ is a vector of village level characteristics, $T$ is the cereal bank dummy $(T=1$ if treated, 0 otherwise), and $\varepsilon(i)$ is the error term. $\alpha$ is the baseline outcome, and $\pi$ and $\beta$ are parameters that need to be estimated. The dummy $T$ is included in Eq. (22.2) to assess the impact of the CDDP treatment on treated and partial control villages. We also estimate the models using fixed effects, comparing the treated villages with the pure control and partial control villages. The combination of fixed-effect estimation and propensity-score matching reduces the selection bias caused by time-invariant missing variable endogeneity or selection on unobservable bias (Duflo et al. 2007).

Two main indicators are identified after reviewing current literature on food and nutrition insecurity.

\section{Food Gap Effects}

The food gap, a proxy for food availability, is the number of months in a year households report having inability to satisfy their food needs (Maxwell and Smith 1992). Households and communities in the Gambia with food deficit experience food gap because of the unavailability or high cost of food during the lean period. This affects food and micronutrient intakes as well as farm investments and yields. We therefore use the food gap as a measure of household food availability.

Comparing with pure control and partial control villages, villages with cereal banks saw a significant reduction in food gap, with and without fixed effects 
(Table 22.3). Middlemen reduce the food gap as well, even though the extent of their influence is debatable. The distance of a village to a main road, which is a proxy for market access, is positively correlated to the food gap.

The further away a village is from lowland areas, the larger the food gap is. This is understandable since lowland areas have higher crop-growing potentials and can allow for off-season gardening (Ceesay 2004). Some of the lowland villages are also able to practice double cropping of rice (von Braun et al. 1989; Carney 1992).

The prices of food crops during the lean period (July-September) also significantly increased the food gap in all cases. Thus, managing inter-seasonal prices could be an effective way of shortening the lean period in rural areas of the Gambia.

Although the CDDP intervention reduced food gap, it does not significantly shorten the lean period. This is because the CDDP had various other community subprojects, some of which may not have a direct and immediate impact on food production and smoothing consumption. Using fixed effects is important because it increases the precision of our model, evident in the $R^{2}$ and the standard error values of our treatment variables.

\section{Price Variability}

Inter-seasonal changes in prices of the three major crops in the Gambia ${ }^{7}$ is a proxy for food accessibility. In Amartya Sen's book Poverty and Famines written in 1981, he argued that the problem of hunger or food insecurity is not only about food availability, but there could also be structural, cultural, or economic circumstances that deny some people access to food, even when food is available. Thus, some of the key indicators of food insecurity include household income, food prices, and household expenditure (von Braun 2011). High food prices during the lean period inhibit food-deficit poor households from buying and consuming adequate amount of food (Gilbert 2012). When food prices are high, poor households in rural areas often adopt various strategies to alleviate the situation. These strategies include reducing frequency and quantity of food intake, foregoing other basic needs, and taking out loans or working to purchase food. The strategies can, however, further exacerbate their indebtedness and poverty (Action Aid 2011). To capture the changes in inter-seasonal price variability, we constructed a price variability model:

$$
\log \left(P_{1}-P_{\mathrm{h}}\right)=\alpha(w)+\pi V(i)+\beta T(i)+\delta \operatorname{CDDP}(i)+\varepsilon(i),
$$

where $P_{1}$ and $P_{\mathrm{h}}$ are prices of food crops during lean period and harvest period respectively.

Our results in Table 22.4 show that cereal banking leads to a significant reduction in the inter-seasonal food price deviation between harvest and lean period. The

\footnotetext{
${ }^{7}$ Rice, millet, and groundnut
} 


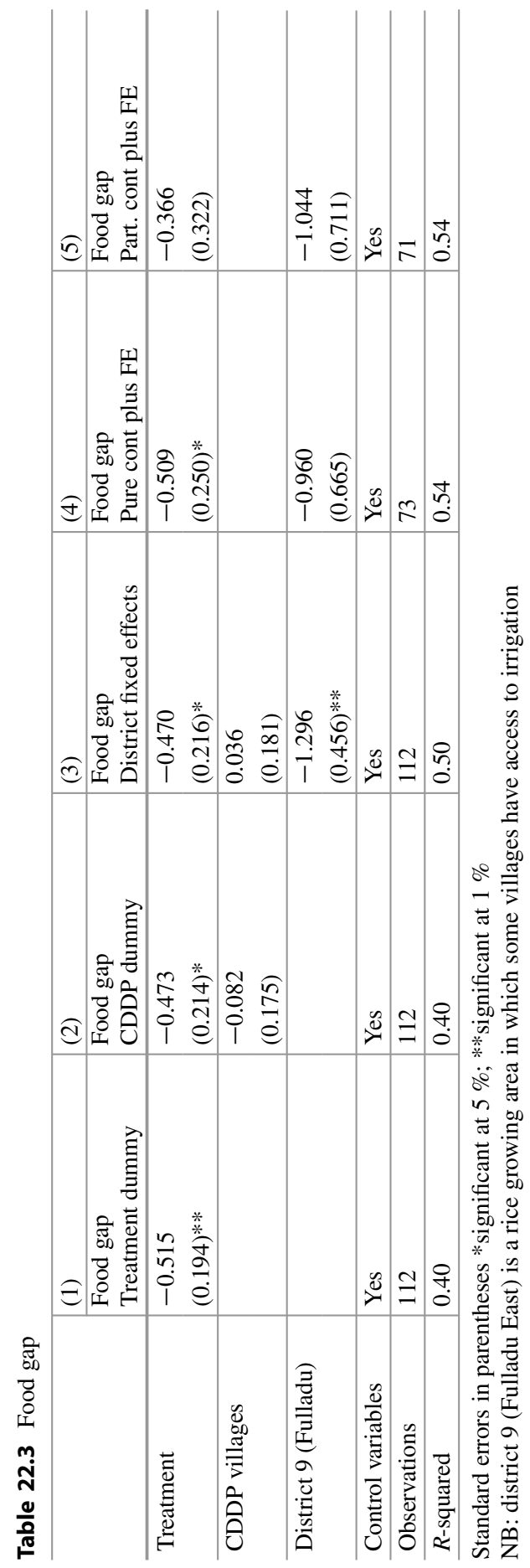




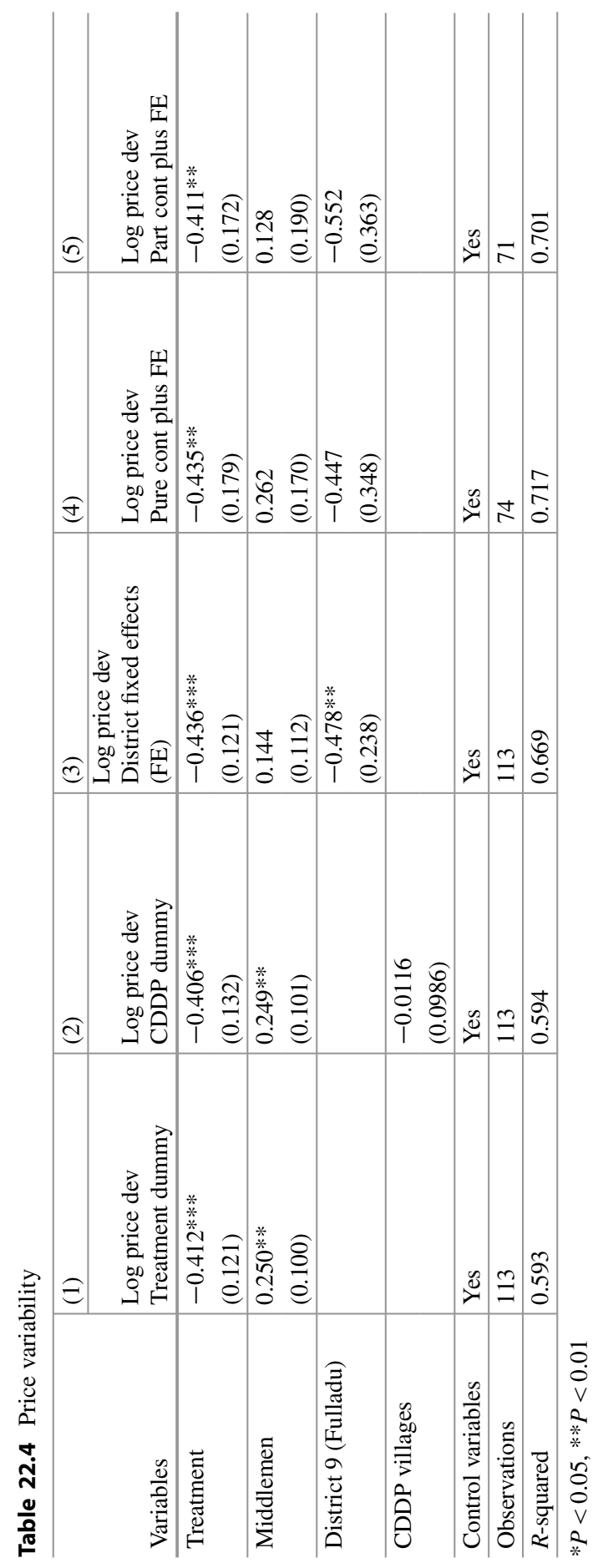


coefficient on the treatment indicates that cereal banking reduced inter-seasonal price changes by an average of $41 \%$.

Similar to findings in another study (Oguoma et al. 2010), our results show that the speculative behavior of middlemen increases inter-seasonal food price variability. The influence of middlemen on the market, prices, and food security at the local level is debatable; most evidence indicates that middlemen exploit farmers and erode profits. Oguoma et al. (2010) argued that the intervention by middlemen increases buying prices for consumers and reduces selling prices for producers, lowering the farmers' profit margins. Often the middlemen engage in temporary arbitrage (Kent 1998), which may also cause the food prices to increase further. This negatively affects the food security of farmers, who shift from being net seller at harvest to net buyers during the lean periods (Bhattamishra 2012).

The district dummies in the fixed-effect model highlighted the importance of double cropping, a practice applicable to district 9 (Fulladu East). In contrast to district 1, district 9 saw a reduction in the inter-seasonal price deviation and food gap.

Other social indicators are changes in demographic characteristics, population growth, and membership in Ward Development Committee (WDC) - a proxy for social capital (Jaimovich 2012). The cereal banking scheme provides a platform for debates about community actions, and gives members an opportunity to organize and manage a program for their community. Over time, the social interaction within a community may enhance intra-village social relations and build the capacity of the community to participate and contribute to other development initiatives.

\subsection{Conclusion}

The results support the hypothesis that cereal banking is an important part of enhancing the food and nutrition security of communities by improving food availability, accessibility, and stability. Cereal banking could reduce food price variability and food gap by more than $25 \%$. This can be attributed to communities having sufficient food during the lean periods, thus reducing speculations.

While community cereal banking schemes may be effective in addressing interseasonal price variations and idiosyncratic risks, they are less effective against covariate risks, especially climate risks. In addition to the risk of embezzlement, there is a high failure rate during periods of poor rainfall.

The results of the propensity-score matching analysis emphasize the need to target a program at appropriate villages based on village characteristics, which influence the choice, sustainability, and impact of the program.

Compared with food aid or humanitarian aid, cereal banking is a more engaging solution that helps vulnerable communities to secure their livelihood and build up their resilience. It empowers affected households to participate and take up ownership. Thus, it could be an effective and participatory channel for food aid delivery during drought. This is very important because price and climate risks are reoccurrences (Cortès and Carrasco 2012). 
While food reserves at the macro level require more careful management and present a large logistical and financial challenge, cereal banking at the community level has the unique advantage of being less cumbersome-the closer proximity to vulnerable communities results in lower transportation and administrative costs (Coulter 2009).

\section{Appendix}

Table 22.5 Test of differences (matched treated and control villages)

\begin{tabular}{|c|c|c|c|c|c|c|c|}
\hline Variable & Sample & Treated & $\begin{array}{l}\text { Partial } \\
\text { control }\end{array}$ & $T$-stat & Treated & $\begin{array}{l}\text { Pure } \\
\text { controls }\end{array}$ & $T$-stat \\
\hline \multirow{2}{*}{$\begin{array}{l}\text { Coefficient of } \\
\text { variation-price }\end{array}$} & Unmatched & 0.2647 & 0.2428 & 2.92 & 0.264 & 0.247 & 1.68 \\
\hline & Matched & 0.2644 & 0.2625 & 0.19 & 0.264 & 0.266 & -0.18 \\
\hline \multirow[t]{2}{*}{ Poverty index } & Unmatched & 0.7061 & 0.6543 & 2.7 & 0.7061 & 0.6604 & 2.262 \\
\hline & Matched & 0.7061 & 0.732 & -1.23 & 0.7061 & 0.705 & 0.053 \\
\hline \multirow[t]{2}{*}{ Millet grown } & Unmatched & 227.289 & 148.82 & 2.15 & 227.29 & 170.247 & 1.41 \\
\hline & Matched & 227.289 & 221.77 & 0.08 & 227.29 & 178.034 & 0.8 \\
\hline \multirow{2}{*}{$\begin{array}{l}\text { Availability of } \\
\text { fruit trees }\end{array}$} & Unmatched & 4332.19 & 5795.61 & -1.61 & 4332.191 & 5281.032 & -1.13 \\
\hline & Matched & 4332.19 & 3811.68 & 0.76 & 4332.191 & 3165.702 & 1.83 \\
\hline \multirow[t]{2}{*}{ Pp of crop farmers } & Unmatched & 0.9657 & 0.921 & 4.14 & 0.966 & 0.927 & 3.76 \\
\hline & Matched & 0.96574 & 0.9681 & -0.41 & 0.966 & 0.97 & -0.83 \\
\hline \multirow[t]{2}{*}{ Av. HH size } & Unmatched & 11.419 & 11.12 & 0.62 & 11.419 & 11.245 & 0.35 \\
\hline & Matched & 11.419 & 11.64 & -0.33 & 11.419 & 11.71 & -0.44 \\
\hline \multirow[t]{2}{*}{ No daily market } & Unmatched & 81.476 & 62.65 & 4.24 & 81.477 & 66.731 & 3.46 \\
\hline & Matched & 81.47 & 82.54 & -0.27 & 81.477 & 80.683 & 0.2 \\
\hline \multirow{2}{*}{$\begin{array}{l}\text { Distance from } \\
\text { market }\end{array}$} & Unmatched & 43.308 & 41.83 & 0.55 & 43.309 & 40.949 & 0.9 \\
\hline & Matched & 43.3 & 45.168 & -0.77 & 43.309 & 44.634 & -0.53 \\
\hline \multirow{2}{*}{$\begin{array}{l}\text { HHs without } \\
\text { improved } \\
\text { transport }\end{array}$} & Unmatched & 98.22 & 91.72 & 3.43 & 98.23 & 92.968 & 3.06 \\
\hline & Matched & 98.229 & 97.668 & 0.54 & 98.23 & 97.415 & 0.72 \\
\hline \multirow{2}{*}{$\begin{array}{l}\text { Remote and } \\
\text { upland villages }\end{array}$} & Unmatched & 0.5106 & 0.4108 & 1.31 & 0.5546 & 0.4208 & 1.88 \\
\hline & Matched & 0.5106 & 0.5106 & 0 & 0.5546 & 0.55 & 0 \\
\hline
\end{tabular}

Open Access This chapter is distributed under the terms of the Creative Commons AttributionNoncommercial 2.5 License (http://creativecommons.org/licenses/by-nc/2.5/) which permits any noncommercial use, distribution, and reproduction in any medium, provided the original author(s) and source are credited.

The images or other third party material in this chapter are included in the work's Creative Commons license, unless indicated otherwise in the credit line; if such material is not included in the work's Creative Commons license and the respective action is not permitted by statutory 
regulation, users will need to obtain permission from the license holder to duplicate, adapt or reproduce the material.

\section{References}

Abebaw D, Haile MG (2013) The impact of cooperatives on agricultural technology adoption: empirical evidence from Ethiopia. Food Policy 38:82-91

Action Aid (2011) No more food crises: the indispensable role of food reserves. www.actionaid. org

Afrique Verte (2010) Strengthening the capabilities of agricultural organization networks through analysis of the evolution of local grain prices in Burkina, Mali and Niger during the period 2001-2010, December

Angrist JD, Pischke JS (2008) Mostly harmless econometrics: an empiricist's companion. Princeton University Press, Princeton, NJ

Arcand JL, Cen YP, He Y, Diop CIF, Wouabe ED, Garbouj M, Jaimovich D, Zec S (2010) The Gambia CDDP baseline: rural house-hold survey, qualitative survey, village

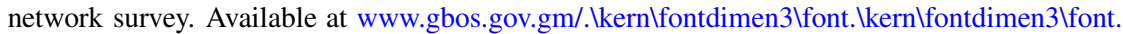
\kernlfontdimen3/font/survey/BASELINE

Baker JL (2000) Evaluating the impact of development projects on poverty: a handbook for practitioners. World Bank, Washington, DC

Barrett CB (1996) Urban bias in price risk: the geography of food price distributions in low-income economies. J Dev Stud 32(6):830-849

Basu K, Wong M (2012) Evaluating seasonal food security programs in East Indonesia

Becker SO, Ichino A (2002) Estimation of average treatment effects based on propensity scores. Stata J 2(4):358-377

Beer F (1990) Cereal banks in Niger. Center for Research on Economic Development, University of Michigan

Bhattamishra R (2012) Grain bank survival and longevity: evidence from Orissa. Margin J Appl Econ Res 6(3):311-336

Caliendo M, Kopeinig S (2008) Some practical guidance for the implementation of propensity score matching. J Econ Surv 22(1):31-72

Carney JA (1992) Peasant women and economic transformation in the Gambia. Dev Change 23(2):67-90

Ceesay MM (2004) Management of rice production systems to increase productivity in the Gambia, West Africa. Doctoral dissertation, Cornell University

Chabé-Ferret S (2010) To control or not to control? Bias of simple matching vs difference-indifference matching in a dynamic framework. In: 10th world congress of the Econometric Society, Shanghai, February, pp 17-21

Cole SA, Giné X, Vickery JI (2012) How does risk management influence production decisions? Evidence from a field experiment. Evidence from a field experiment, 1 July 2013. World Bank policy research working paper (6546)

Cortès GP, Carrasco IG (2012) First line of defence: assessing the potential of local food reserves in the Sahel. Crola 2011

Coulter J (2009) Review of warehouse receipt system and inventory credit initiatives in eastern \& southern Africa. UNCTAD, All ACP Agricultural Commodities Programme (AAACP)

Daviron B, Douillet M (2013) Major players of the international food trade and the world food security. FOODSECURE working paper no. 12

Duflo E, Glennerster R, Kremer M (2007) Using randomization in development economics research: a toolkit. Handbook Dev Econ 4:3895-3962

Ericksen P, Thornton P, Notenbaert A, Cramer L, Jones P, Herrero M (2011) Mapping hotspots of climate change and food insecurity in the global tropics 
Food and Agriculture Organisation (FAO) (2011) The state of food insecurity in the world, How does international price volatility affect domestic economies and food security?

Gilbert CL (2012) International agreements to manage food price volatility. Global Food Secur $1(2): 134-142$

Government of the Gambia (2010) Integrated household survey 2010. www.gbos.gov.gm/Surveys

Heckman J, Ichimura H, Smith J, Todd P (1997) Characterizing selection bias using experimental data (no. w6699). National Bureau of Economic Research

Hoddinott J (1999) Choosing outcome indicators of household food security. International Food Policy Research Institute, Washington, DC

Huchet-Bourdon M (2011) Agricultural commodity price volatility (no. 52). OECD food, agriculture and fisheries working papers

Ivanic M, Martin W (2008) Implications of higher global food prices for poverty in low-income countries. Agric Econ 39(s1):405-416

Jaimovich D (2012) Missing links, missing markets: evidence of the transformation process in the economic networks of Gambian villages. World Dev 66:645-664

Kalkuhl M, Kornher L, Kozicka M, Boulanger P, Torero M (2013) Conceptual framework on price volatility and its impact on food and nutrition security in the short term. LEI Wageningen UR

Kent L (1998) Notes from the workshop on community-level grain storage projects (cereal banks): why do they rarely work and what are the alternatives? 19-22 January. Available at http://www. foodaid.org/

Khandker SR (2009) Poverty and income seasonality in Bangladesh. World Bank policy research working paper series, no. 4923

Laborde Debucquet D, Tokgoz S, Torero M (2013) Long-term drivers of food and nutrition security. LEI Wageningen UR

Maxwell S, Smith M (1992) Household food security: a conceptual review. In: Maxwell S, Frankenberger $\mathrm{T}$ (eds) Household food security: concepts, indicators, measurements. IFAD/UNICEF, Rome/New York

Morduch J (1995) Income smoothing and consumption smoothing. J Econ Perspect 9(3):103-114

Oguoma ON, Nkwocha VI, Ibeawuchi II (2010) Implications of middlemen in the supply chain of agricultural products. J Agric Soc Res 10(2):77-83

Olken B (2012) Monitoring corruption: evidence from a field experiment in Indonesia. J Polit Econ 115(2):200-249

Pangaribowo E, Gerber N, Torero M (2013) Food and nutrition security indicators (no. 5). Working paper

Pieters H, Guariso A, Vandeplas A (2013) Conceptual framework for the analysis of the determinants of food and nutrition security (no. 13). LEI Wageningen UR

Ravallion M (2007) Evaluating anti-poverty programs. Handbook Dev Econ 4:3787-3846, World Bank

Sen A (1981) Poverty and famines: an essay on entitlement and deprivation. Oxford University Press, Oxford

Tadesse G, Algieri B, Kalkuhl M, von Braun J (2013) Drivers and triggers of international food price spikes and volatility. Food Policy 47:117-128

Vicarelli M (2011) Exogenous income shocks and consumption smoothing strategies among rural households in Mexico. Center for International Development, Harvard Kennedy School

von Braun J (2011) Food price volatility and food and nutrition security. Center for Development Research, University of Bonn

von Braun J, Tadesse G (2012) Global food price volatility and spikes: an overview of costs, causes, and solutions. ZEF-discussion papers on development policy (161)

von Braun J, Puetz D, Webb P (1989) Irrigation technology and commercialization of rice in the Gambia, effects on income and nutrition, vol 75. International Food Policy Research Institute, Washington, DC

von Braun J, Teklu T, Webb P (1999) Famine in Africa: causes, responses, and prevention. International Food Policy Research Institute, Washington, DC 
Wheeler T, von Braun J (2013) Climate change impacts on global food security. Science 341(6145):508-513

World Food Programme (WFP) (2011) Comprehensive food security and vulnerability analysis. Available at http://documents.wfp.org/stellent/groups/public/documents/manual_guide_proced/ wfp203208.pdf

Wright B, Cafiero C (2009) Grain reserves and food security in Mena countries. In: UC Berkeley conference on agriculture for development—revisited 